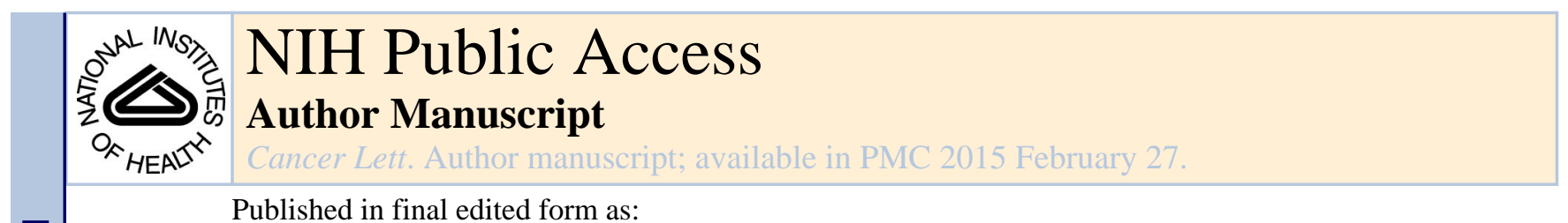

Published in final edited form as:

Cancer Lett. 2010 March 28; 289(2): 140-150. doi:10.1016/j.canlet.2009.07.004.

\title{
Kaposi Sarcoma-associated Herpesvirus (KSHV): Molecular Biology and Oncogenesis
}

\author{
Kwun Wah Wen ${ }^{1,2}$ and Blossom Damania ${ }^{1,2, *}$ \\ ${ }^{1}$ Lineberger Comprehensive Cancer Center. University of North Carolina, Chapel Hill Chapel Hill, \\ NC 27599, USA \\ 2Department of Microbiology \& Immunology, University of North Carolina, Chapel Hill Chapel Hill, \\ NC 27599, USA
}

\begin{abstract}
Kaposi sarcoma-associated herpesvirus (KSHV) is a double-stranded DNA herpesvirus belonging to the gammaherpesvirinae subfamily. KSHV has been associated with the development of three neoplastic diseases: Kaposi sarcoma (KS), primary effusion lymphoma (PEL), and multicentric Castleman disease (MCD). In this review, we discuss the three KSHV-associated malignancies, KSHV genome, latent and lytic aspects of the viral lifecycle, putative viral oncogenes, as well as therapeutic regimens used for the treatment of KS, PEL, and MCD.
\end{abstract}

\section{Keywords}

KSHV; oncogenesis; AIDS-related malignancies; viral latency; lytic replication

\section{Introduction}

The members of the herpesviridae family are well represented in nature and can be found in many different species across the animal kingdom. They are also highly adapted to their hosts and are thought to have coevolved with their hosts for millions of years. Typically, herpesviruses have a double-stranded DNA genome (124-230 kb) enclosed in an icosahedral capsid ( 125 nm in diameter) composed of 162 capsomeres. The capsid structure is surrounded by an amorphous tegument layer that separates it from the outer, glycoprotein-decorated, envelope. Common to all human herpesviruses is their ability to adapt very well to the cellular milieu of the infected host and their ability to evade host immune responses to establish life-long latent infection. Based on their biological properties

\section{(C) 2009 Published by Elsevier Ltd.}

"Corresponding author. Mailing address: Lineberger Comprehensive Cancer Center, CB\#7295, University of North Carolina, Chapel Hill, NC 27599, USA. Phone: (919) 843-6011. Fax: (919) 966-9673. damania@ med.unc.edu.

Disclosure Statement The authors have no conflict of interest to disclose.

Publisher's Disclaimer: This is a PDF file of an unedited manuscript that has been accepted for publication. As a service to our customers we are providing this early version of the manuscript. The manuscript will undergo copyediting, typesetting, and review of the resulting proof before it is published in its final citable form. Please note that during the production process errors may be discovered which could affect the content, and all legal disclaimers that apply to the journal pertain. 
including host range, replication cycle and cell tropism, these viruses are classified into the alpha-, beta-, and gammaherpesvirinae subfamilies [1].

There are eight known human herpesviruses (HHV). Most of the human population is infected with one or more of these viruses, and they rarely cause severe disease in the host unless the host immune system is compromised. Human herpesviruses belonging to the alpha subfamily include herpes simplex viruses (HSV) 1 and 2 (HHV-1 and HHV-2), and varicella-zoster virus (VZV; HHV-3). Members of the human betaherpesvirinae include cytomegalovirus (CMV; HHV-5), HHV-6 variants A and B, and HHV-7. Human gammaherpesvirinae include Epstein-Barr virus (EBV; HHV-4) and Kaposi sarcomaassociated herpesvirus (KSHV; HHV-8). Strikingly the members of gammaherpesvirinae are strongly associated with neoplastic disease. For example, EBV is distinctly associated with Burkitt's lymphoma, Hodgkin's lymphoma, nasopharyngeal carcinoma, $\mathrm{T}$ and natural killer cells lymphoma, and post-transplant lymphoma [2;3;4;5]. KSHV is the etiological agent of several human cancers including Kaposi sarcoma (KS) [6; 7], primary effusion lymphoma (PEL) [8], and the plasmablastic variant of multicentric Castleman disease (MCD) [9; 10]. Additionally, there have also been reports of KSHV-associated solid lymphomas of HIVpositive and negative individuals [11] as well as KSHV-associated lymphomas in patients with primary immunodeficiencies such as common variable immunodeficiency [12].

The gammaherpesviruses have evolved to possess a plethora of viral gene products that intricately subvert normal cellular pathways. The dysregulated signaling pathways include those involved in cell cycle progression, apoptosis, immune surveillance, and antiviral responses. Gammaherpesviruses are masters of altering these pathways in favor of their survival. They are known to establish persistent viral infection, and to evade viral clearance by actively suppressing apoptosis and escaping immune detection. The survival mechanisms used by these viruses are thought to inadvertently contribute to host cell transformation and the development of neoplasia, which is most frequently seen in the setting of immunodeficiency. In this review, we will focus on KSHV in terms of its associated clinical diseases and current therapies, as well as viral genes implicated in tumorigenesis and oncogenesis.

\section{Clinical diseases associated with KSHV infection}

\subsection{Kaposi sarcoma}

Kaposi sarcoma was named by Dr. Moritz Kaposi, a prominent Hungarian dermatologist, who first described the rare classical form of KS as "idiopathic multiple pigmented sarcoma of the skin" in 1872 [13]. Since the 1950s, an infectious agent was suspected to cause KS. The discovery of the causative agent of KS, however, was not intensively pursued until the early 1980s, when the incidence of KS dramatically increased in homosexual and bisexual HIV-positive individuals during the AIDS epidemic. The sudden surge of KS incidence among HIV-infected individuals strongly suggested an infectious agent was involved in the development of KS. In 1994, Chang and Moore used representational difference analysis to characterize DNA fragments obtained from KS biopsies and established an association of a novel human gammaherpesvirus with KS [6]. This newly identified virus was named KSHV. KS is a highly vascular tumor of endothelial lymphatic origin $[14 ; 15]$. 
Histologically, the signature KSHV-infected cells are spindle-shaped, poorly differentiated, and highly proliferative [16]. KS is also characterized by extravasation of erythrocytes, infiltration of inflammatory cells (macrophages, lymphocytes and plasma cells) and neoangiogenesis [17]. Clinically, KS is characterized by dermatological lesions that are red, brown, or purple in pigmentation. These lesions can be found cutaneously, mucosally, or viscerally. KS can be staged by six overlapping clinicopathologic forms: patch, plaque, nodular, lymphadenopathic, infiltrative, and florid [18; 19]. It is important to note that greater than $95 \%$ of KS lesions contain KSHV viral DNA. Based on epidemiological and clinical outcomes, KS can be classified into 4 different clinical subtypes. These are classic/ sporadic, endemic/African, epidemic/AIDS-associated, and iatrogenic/post-transplant. Classic KS is the form described by Dr. Kaposi. The presentation of classic KS typically occurs with an indolent course in Mediterranean and Eastern European elderly men over 50 years of age. The lesions are generally localized in the upper and/or lower extremities without much involvement with, or spreading to, the lymph nodes and internal organs. Patients diagnosed with classic KS may progress to other secondary malignancies, primarily non-Hodgkin's lymphomas (NHL) [20; 21]. African endemic KS is commonly seen in Eastern and central African countries such as Uganda, Malawi, and Kenya. Endemic KS may be indolent or aggressive, with more lymph node involvement than classic KS. The aggressive form (also known as lymphadenopathic form) of endemic KS is more commonly found in children at pre-puberty ages, with high fatality rates [22]. AIDS-associated KS is the most common and aggressive variant, with the most lymph node/visceral spreading amongst all KS subtypes [23; 24]. During the HIV/AIDS epidemic, the incidence of KS concurrently peaked with HIV diagnoses. Due to its strong association with AIDS, KS was identified as an AIDS-defining illness and served as a marker for HIV disease in the mideighties [25]. Indeed, KS is the most common malignancy associated with HIV infection and can lead to significant mortality [26]. KS is the most common tumor in African men [27; 28; 29]. This epidemiologic form of KS is found with increased frequency in homosexual AIDS patients who are relatively young. With the advent of highly active antiretroviral therapy (HAART) in the 1990s, the incidence and mortality of AIDS-associated KS have dramatically dropped [30; 31]. However, KS continues to remain the most common AIDSassociated cancer in developed nations and in developing countries [32]. Another form of $\mathrm{KS}$, known as iatrogenic/post-transplant KS, is associated with immune suppression after long-term immunosuppressive therapy used to prevent rejection of solid allografts [33]. Renal transplant patients are the most likely group to develop this form of KS. Interestingly, the KSHV-infected endothelial cells or lymphocytes found in KS lesions in these patients can originate from donor tissues [34]. Reduction or withdrawal of immunosuppressive therapy has been shown to be effective in resolving iatrogenic KS. However, this also increases the likelihood of allograft rejection.

\subsection{Primary effusion lymphoma}

In addition to KS, primary effusion lymphoma (PEL), sometimes referred to as body cavitybased lymphoma (BCBL), has been strongly associated with KSHV [8]. PEL is a unique form of NHL found more commonly in immunocompromised AIDS patients. Unlike KS, PEL is derived from clonally expanded malignant B cells and presents as a lymphomatous effusion tumor contained in various body cavities such as the pericardium, pleurum, and 
peritoneum. There are, however, reports of PEL as a solid mass in lymph nodes and other organs [35]. PEL is aggressive and rapidly progressing, and can cause high fatality. The mean survival time for patients with PEL is approximately two to six months [36].

Histologically, PEL cells are larger than normal lymphocytes and erythrocytes, and contain features of both large cell immunoblastic lymphoma and anaplastic large cell lymphoma. PEL cells express CD45, activation-associated antigens, clonal immunoglobulin rearrangements but usually lack B cell-associated antigens [37]. PEL cells can be KSHV single-positive or KSHV/EBV double-positive. KSHV genomes are found in PEL cells at a high copy number (50-150 viral genomes per infected cell) [8;38;39].

\subsection{Multicentric Castleman disease}

The plasmablastic variant of multicentric Castleman disease (MCD) is also highly associated with KSHV; however, the other form of MCD, namely, the hyaline variant of MCD, is not. $\mathrm{MCD}$ is a reactive lymphadenopathy that is considered non-neoplastic as polyclonal B-cell populations are usually found in the lesion. However, monoclonal B cell expansion has also been reported for plasmablastic MCD [40; 41]. Plasmablastic MCD can have an aggressive and rapid progression leading to high fatality. Histologically, germinal center expansion and vascular endothelial proliferation occur within the involved lymph nodes of MCD.

Dysregulated IL-6 levels, likely contributed in part by virally encoded IL-6 (vIL-6) [42], may account for the clinico-pathophysiology of MCD. Like KS and PEL, KSHV genomes are detectable in almost all HIV-positive MCD cases and about fifty percent of HIVnegative MCD cases. [10; 16]. Additionally, KSHV has been shown to be associated with a plasmablastic variant of MCD.

\section{The KSHV genome}

KSHV has a double-stranded DNA genome and its size ranges from 165-170 kb [43; 44]. The long unique region (LUR), which is about 138 to $140.5 \mathrm{~kb}$ in length and contains all of the KSHV ORFs, is flanked by terminal repeat (TR) sequences at both ends of the linear viral genome. Each TR is $801 \mathrm{bp}$ in length and is highly GC-rich. The number of TRs varies among KSHV isolates, ranging from 16 to 75 [45], which accounts for the variation in the genome sizes of KSHV isolates. The KSHV genome exhibits very high degree of similarity to retroperitoneal fibromatosis-associated herpesvirus (RFHV) and rhesus monkey rhadinovirus (RRV) in the rhadinovirus subfamily of gammaherpesvirinae. RFHV appears to be more closely related to KSHV. Although many of the KSHV ORFs are conserved in alpha- and beta-herpesviruses, the virus does contain a significant number of unique ORFs not found in other herpesviruses (Table 1). These KSHV-specific ORFs are designated K1 to K15, based on their relative locations (from left to right) in the KSHV genome (Figure 1). Moreover, KSHV also contains several viral genes that have been pirated from the host genome and are homologues of cellular genes [46].

Many viral genes are involved in signal transduction (e.g. K1, K15), cell cycle regulation (e.g. vCyclin, LANA-1), inhibition of programmed cell death (e.g. K1, vFLIP, vBcl-2) and immune modulation (e.g. viral chemokine receptors, vIRFs, K3, K5). Additionally, a number of KSHV genes are expressed by alternative splicing (reviewed in [47]), by the use of alternative transcriptional start sites, or internal ribosome entry sites (IRES) [48; 49]. 
Very recently, a total of 12 microRNAs have been discovered in the KSHV genome [50; 51; 52; 53]. Ten of these microRNAs were found in the non-coding region between K12/ Kaposin and K13/Orf71/vFLIP, and two were located within the K12 ORF (Figure 1). All of the KSHV microRNAs were expressed during latency [50; 54; 55; 56], with a sub-set of these microRNAs being upregulated during the lytic cycle. Recent evidence has identified cellular and viral targets of these microRNAs, as well as their roles in KSHV pathogenesis [54; 55; 57; 58; 59]. Besides microRNAs, KSHV also produces a non-coding RNA transcript that is $1077 \mathrm{bp}$ in size, polyadenylated and exclusively nuclear (PAN) [60;61; 62; 63]. PAN RNA is made during the lytic cycle and has been shown to retain intronless RNA in the nucleus and block the assembly of an export-competent mRNP.

\section{The viral lifecycle}

Like other herpesviruses, KSHV displays two different phases of its viral lifecycle. Latent KSHV is characterized by a circularized, extra-chromosomal viral genome (episome) and the expression of a very small subset of latent transcripts in the infected cells; no functional or infectious viral particles are produced during latency. In latently infected cells, in all three KSHV-associated malignancies, the expression of OrfK12/Kaposin, K13/Orf71/vFLIP, Orf72/vCyclin, and Orf73/LANA has been detected. In PEL and MCD cells, OrfK10.5/ LANA-2/vIRF3 expression was also detected [64]. The lytic cycle is characterized by the replication of linear viral genomes, and the expression of more than 80 transcripts in a highly orchestrated temporal order of immediate-early $(\alpha)$, early $(\beta)$, and late $(\gamma)$ categories. These categories are defined by sensitivity to cycloheximide and phosphonoacetic acid (PAA) treatment after chemical induction of viral reactivation $[65 ; 66 ; 67 ; 68]$. Unlike early and late genes, immediately-early (IE) genes are not sensitive to the protein synthesis inhibitor cycloheximide, as the expression of IE genes does not rely on viral protein synthesis. IE genes are important for regulating the subsequent transcriptional cascade. KSHV encoded Rta is an IE lytic master switch protein that has been shown to be required and sufficient for initiating the lytic replication cycle to completion. The IE gene K8/K-bZIP appears to antagonize Rta transactivation activity $[69 ; 70]$. The third IE gene, Orf45, is important for the suppression of interferon induction by lytic viral infection or reactivation [71]. In contrast to IE genes, early and late genes are not sensitive to cycloheximide, and are distinguished by their dependence on DNA replication. The expression of early genes is independent of viral DNA synthesis and is not inhibited by PAA treatment, whereas the expression of late genes is dependent on the replication of viral genomes and therefore sensitive to PAA inhibition. To model KSHV lytic replication in vitro, chemical induction using $n$-butyrate and 12-O-tetradecanoylphorbol-13-acetate (TPA) to reactivate PEL cells has been reported. TPA treatment can lead to reactivation in about 20-30\% of PEL cells [43; 72]. The general function of early and late genes is to facilitate the replication of viral genomes, viral assembly and egress.

\section{Putative viral genes involved in KSHV transformation and oncogenesis}

Transformation is a key event in the multistep process of oncogenesis. It involves changes in cellular signaling pathways and cell morphology, leading to a state of uncontrolled proliferation. In KSHV, transformation of endothelial cells can lead to chromosome 
instability [73], alteration of cellular gene expression profiles [74], acquisition of telomerase activity and anchorage-independent growth [75], increase in cell invasiveness [76] as well as long-term proliferation and survival of these cells [75; 77]. A number of KSHV-encoded proteins are believed to have transforming and oncogenic properties. They include both latent and lytic proteins: the latent proteins are likely to enhance the survival and proliferation of the infected cells, whereas the lytic viral proteins are believed to mediate paracrine secretion of growth and angiogenic factors essential for tumor growth and development. This is postulated based partially on the observation that the latent genes (especially those encoded on the latency-associated cassettes) are detectable in situ in the majority of KS, PEL, and MCD samples, whereas the lytic genes (e.g. K1, vIL-6, vGPCR) are detectable in only small sub-sets of tumor samples. These oncogenic viral products are described below.

\subsection{LANA}

In addition to its role in the establishment and maintenance of latency (reviewed in [78; 79; 80]), the latency-associated nuclear antigen (LANA) can perturb a plethora of cellular pathways to contribute to tumorigenesis. For example, LANA can physically associate with p53 and inhibit p53-mediated transcription activity and apoptosis [81]. LANA can also inactivate the tumor suppressor retinoblastoma $(\mathrm{Rb})$ gene and release E2F transactivator which induces cell to transit through the G1/S cell cycle checkpoint [82]. To promote G1/S transition, LANA interacts with the bromodomain-containing protein RING3/Brd2 [83; 84; $85 ; 86]$, and can sequester glycogen synthase kinase (GSK)-3 $\beta$ in the nucleus, which prevents GSK-3 $\beta$ from complexing with, and degrading, $\beta$-catenin in the cytoplasm. The stabilized $\beta$-catenin can translocate into the nucleus, where it complexes with the transcription factors lymphoid enhancing factor (LEF) and T-cell factor (TCF) to transactivate responsive genes including CCND1 and Myc, which have been implicated in cell cycle regulation and oncogenesis $[87 ; 88]$. LANA can cooperate with the oncogene $\mathrm{H}-$ Ras to transform primary rat embryo fibroblasts and render them tumorigenic [82]. LANA was also shown to upregulate human telomerase reverse transcriptase (hTERT) gene expression and to immortalize primary HUVEC and increase their proliferation [89]. Finally, transgenic mice expressing LANA under the endogenous LANA promoter developed splenic follicular hyperplasia with increased germinal centers as well as lymphomas [90]. Based on these findings, LANA appears to at least set the initial stage for sarcomagenesis and lymphomagenesis.

\subsection{K13/vFLIP}

The viral FLICE (Fas-associated death-domain like IL-1 beta-convertase enzyme) inhibitory protein (vFLIP) is also known as K13, and is encoded by Orf71 [66; 67; 91]. Latent expression of vFLIP occurs via splicing of the LANA transcript from the tricistronic messenger RNA, and via the use of the IRES in vCyclin coding sequences [49; 92; 93]. Similar to cellular FLIPs, vFLIP inhibits death receptor signaling by specifically abrogating the interaction between Fas-associated death domain (FADD) and caspase-8 [94]. The inhibition of this pathway blocks Fas-mediated apoptosis, thus providing a survival advantage for KSHV-infected cells [95]. In addition to blocking the extrinsic apoptotic pathway, vFLIP also associates with the IKK complex and the heat shock protein 90 (hsp90) 
to induce NFkB survival signaling [96; 97; 98; 99]. The induced NFkB signaling is significant in at least two aspects: viral latency and oncogenesis. First, NFผB activation by vFLIP is critical for vFLIP inhibition of lytic replication via the AP-1 pathway [100; 101]. Second, the enhanced $\mathrm{NF \kappa B}$ signaling may be important for the transforming and oncogenic potential of vFLIP as demonstrated in Rat-1 fibroblast assays and tumors in nude mice [102]. In primary dermal microvascular endothelial cells, vFLIP expression was shown to induce anoikis (detachment induced apoptosis), but not apoptosis, due to growth factor depletion suggestive of its role in paracrine factor secretion and KS development [103].

\subsection{Kaposin}

The Kaposin transcripts represent the most abundantly expressed viral transcripts during KSHV latency. Kaposin A is encoded by OrfK12, while Kaposins B and C initiate upstream of OrfK12 at two repeat regions (termed DR1 and DR2), and their transcripts extend into OrfK12 [104]. Kaposin A has oncogenic potential as demonstrated by focus formation assay in transfected Rat-3 cells. This morphological change is mediated through interaction with cytohesin-1 [105]. Cytohesin-1 is a guanine nucleotide exchange factor for the GTPase ARF as well a regulator of cell adhesion. When injected into athymic mice, the transformed Rat-3 cell lines containing Kaposin sequences produced high-grade, highly vascular, undifferentiated sarcomas [106]. In contrast to the undetectable protein level of Kaposin A in virus-infected cells, Kaposin B was shown to be the most abundant Kaposin protein in the PEL cell line BCBL-1 [104]. Kaposin B functions to stabilize cytokine expression such as IL- 6 and GM-CSF by inhibiting degradation of their messages. The inhibition was achieved via Kaposin B binding and activation of MK2 kinase, which inhibits degradation of mRNA containing AU-rich elements (e.g. cytokines) [107]. The mRNA stabilization activity is dependent on the direct repeat (DR1 and DR2) elements of Kaposin B [108].

\subsection{K1}

$\mathrm{K} 1$ is a 46-kDa type I membrane glycoprotein encoded by the first open reading frame [109]. K1 is also designated VIP (variable ITAM-containing protein) as it contains an immunoreceptor tyrosine-based activation motif (ITAM) [110]. K1 demonstrates early lytic kinetics and its expression has been detected in KS, PEL, and MCD [67; 109; 111; 112]. K1 has been shown to transform Rat-1 rodent fibroblasts by inducing morphological changes and foci formation [113], and can functionally substitute for STP in the context of HVS infection to immortalize T lymphocytes to IL-2-independent growth as well as induce lymphomas [113]. Transgenic mice expressing the K1 gene showed constitutive activation of NF- $\kappa$ B and Oct-2, increased Lyn tyrosine kinase phosphorylation and activity, as well as increased basic fibroblast growth factor (bFGF) expression [114]. Some of these mice developed tumors with features resembling the spindle-cell sarcomatoid tumor and malignant plasmablastic lymphoma [114].

Structurally, K1 contains a long N-terminal extracellular domain, a transmembrane domain, and a short C-terminal cytoplasmic tail. The $\mathrm{C}$-terminus of $\mathrm{K} 1$ is well conserved and contains an ITAM that is normally important for lymphocyte activation signaling [110]. K1 appears to be constitutively active and independent of ligand binding [113]. In B cells, K1 has been shown to activate PI3K (p85 subunit), Akt, Vav, and Syk kinases, and to induce 
NFAT and NFkB transcriptional activities for cell survival [110; 115; 116]. In addition, K1 can prevent death receptor-mediated apoptosis of B lymphocytes by inhibiting the induction of FasL expression and activating the PI3K/Akt pathway [115]. Another striking feature of $\mathrm{K} 1$ is the induced downregulation of surface $\mathrm{B}$ cell receptor by endoplasmic reticular sequestration [117]. This may inhibit apoptosis as a consequence of BCR signaling. K1 signaling activity in B-cells has been linked to K1 internalization and since K1 also cointernalizes with BCR, it suggests a possible mechanism of BCR downregulation from the cell surface [118]. In epithelial and endothelial cells, K1 expression induced the secretion of angiogenic factors, including vascular endothelial growth factor (VEGF) and matrix metalloproteinase-9 [119]. K1 also activated the PI3K/Akt/mTOR pathway in endothelial cells [111]. In endothelial cells, K1 has been shown to immortalize and extend the life span of primary human umbilical vein endothelial cells (HUVEC) in culture [111]. K1 ITAM expression also activates both the VEGF/VEGFR-2 and the PI3K/Akt signaling pathways in HUVEC [111]. Cumulatively, these data suggest a paracrine model in which K1-mediated secretion of cytokines is involved in the development of KSHV-associated diseases [119]. Thus K1 appears to be important in KSHV associated tumorigenesis and angiogenesis.

\section{5. vGPCR}

Viral G-protein-coupled receptor is encoded by Orf74 of KSHV [120; 121]. It is expressed early during the lytic cycle and is a viral homologue of the cellular angiogenic IL-8 receptor [122]. vGPCR possesses seven transmembrane domains that are universally found in cellular GPCRs [122]. The expression of vGPCR can be found in only a small fraction of KS, PEL, and MCD samples [123]. This protein has potent oncogenic activities, as evidenced by its ability to transform and form foci in murine NIH3T3 cells as well as to produce tumors when injected into nude mice [124]. Like K1, vGPCR can immortalize HUVEC and protect these cells from apoptosis induced by serum starvation [125; 126]. A sub-set of vGPCR transgenic mice developed KS-like angioproliferative lesions with surface markers and cytokine profiles resembling those of KS [127; 128; 129]. As observed in KSHV-associated malignancies, the expression of vGPCR was detected in only a small population of cells in the transgenic tumors and in a few other tissues, suggesting that vGPCR-mediated tumor formation is driven by spontaneous lytic reactivation in the background of latently infected cells. VEGF secretion was increased in these vGPCRinduced tumors [127]. Unlike its cellular homologues, vGPCR signaling is constitutive and independent of ligand binding [130]. vGPCR can activate mitogen-activated protein kinases (MAPKs)[123], PLC [126], PI3K [126], and Akt [125] in endothelial cells. These data implicate that like KSHV K1, autocrine/paracrine signaling of vGPCR might contribute to KSHV-associated oncogenesis and angiogenesis.

\section{6. vIL-6}

Viral interleukin-6 encoded by OrfK2 is a homologue of cellular IL-6 (24.6\% amino acid sequence identity) [46]. Viral IL-6 expression can be detected in KS, PEL, MCD samples to different extents (MCD>PEL $\gg \mathrm{KS}$ ) [64; 131]. Interestingly, IL-6 overexpression was suspected to be important in KS and MCD pathogenesis, prior to the discovery of KSHV [132; 133]. Similar to cellular IL-6, vIL-6 signaling triggers the JAK/STAT (Janus tyrosine kinases signal transducers and activators of transcription) [134], MAPK, and H7-sensitive 
pathways [135]. The JAK/STAT pathway induced by vIL-6 results in increased VEGF expression and signaling in an autocrine/paracrine fashion [136]. Unlike its cellular IL-6 homologue, whose signaling depends upon both gp80 (IL-6Ra) and gp130, vIL-6 signaling can be achieved through gp130 alone [134]. Therefore, vIL-6 seems to bypass the normal cellular checkpoint of gp80 coupling with gp130 for IL6 binding. Innoculation of NIH3T3 cells stably expressing vIL-6 into athymic mice resulted in tumor formation, hematopoiesis, and plasmacytosis compared to the control mice. The vIL-6-expressing tumors were also more vascularized, which correlated with an elevated level of VEGF secretion [137].

\section{7. vIRF-1}

The viral interferon regulatory factor-1 is encoded by KSHV OrfK9 [138; 139]. In contrast to the other three KSHV-encoded IRFs, the vIRF-1 transcript is unspliced. In PEL cells, the expression of vIRF-1 is low during latency but can be induced to high levels during lytic infection [140]. The most apparent function of vIRF-1 is to suppress both type I and type II interferon responses [139; 141; 142]. vIRF-1 can compete with cellular IRF3 to interact with the transcriptional coactivator CBP and $\mathrm{p} 300$. This interferes with the formation of the IRF3/CBP/p300 complexes [141;143]. In addition to suppressing the host anti-viral response, vIRF-1 can block apoptosis induced by tumor necrosis factor a (TNFa) and p53, respectively [141; 144]. Viral IRF-1 can physically associate with p53 and repress its transactivation and apoptotic functions through inhibition of p53 phosphorylation and acetylation [144; 145]. Viral IRF-1 is a potential oncogene, as NIH3T3 cells stably expressing vIRF-1 can grow under conditions of serum deprivation. These cells exhibit loss of contact inhibition in soft agar and can form tumors in nude mice [142]. Transformation of vIRF-1 expressing NIH3T3 cells was found to be mediated by the induction of Myc protooncogene through vIRF-1 activation of the plasmacytoma repressor factor (PRF) element [146].

In addition to their transforming/oncogenic properties in overexpression systems (in isolation), most of the putative oncogenic KSHV gene products (e.g. LANA, vCyclin, vFLIP, vIL-6, Kaposin B, K1, vGPCR, vIRF-1) described in this section can be detected in KS, PEL, and MCD specimens, albeit with differential contribution (Table 1). This further corroborates their important roles in the initiation and/or maintenance of KSHV-associated malignancies. Very generally speaking, predominantly latent proteins are expressed in KS and PEL cells, but both latent and lytic proteins are expressed in MCD. Intriguingly, processivity factor-8 (PF-8)/Orf59 and vIRF-1 can be detected in PEL cell line but not in PEL primary tissues $[64 ; 147]$. Furthermore, PEL cell lines require chemical induction to express vIL-6 while primary PEL tumor cells express vIL-6 without the dependence of lytic reactivation $[64 ; 131 ; 148]$. The discrepancies could be due to the loss of tumor microenvironment in cell lines or adaptation of PEL cells during passages. This may raise a potential problem of using PEL cell lines to extrapolate the PEL disease state.

Although we have not described the functions of all the unique genes encoded by KSHV due to space restrictions, a brief description of these genes is listed in Table 2. 


\section{Treatment of KS, PEL, and MCD}

Treatment options for KS are based on disease severity, the KS subtype, and immune status. For relatively mild and limited KS, local treatment options such as topical alitretrinoin, surgical excision, radiation therapy, and intralesional chemotherapy (e.g. vinblastine) can be used to treat the symptoms. These local therapies do not prevent new KS lesions from developing. For more severe and aggressive KS, systemic chemotherapy with agents such as liposomal anthracyclines (doxorubicin and daunorubicin; first-line) and paclitaxel (secondline) is usually the mainstay of treatment. Other chemotherapeutics include vinorelbine, interferon- $a$, and interleukin-12. Although the approaches mentioned above have some beneficial effects to the patients, they are not very effective, as they do not target specifically the agent causing the tumor. The mTOR inhibitor, rapamycin (Sirolimus) was tested against iatrogenic KS and was highly successful [149; 150]. In AIDS-KS patients, HAART is recommended to reduce the extent and size of KS lesions. HAART might also reduce the incidence of new KS in HIV-positive individuals. These beneficial effects are likely due to immune reconstitution. In addition to HAART, the tyrosine kinase inhibitor imatinib, and IL-12 also demonstrate some activities against AIDS-KS [151; 152].

PEL patients have very poor prognosis and have a median survival of only two to three months after diagnosis. As in the case of KS, a patient co-infected with HIV is likely to benefit from HAART [153]. Complete remission of PEL with HAART is seen occasionally $[153 ; 154 ; 155]$. On the other hand, conventional CHOP-like regimens (cyclophosphamide, doxorubicin, vincristine, and prednisone) did not improve survival compared to other HIVassociated NHL [154]. For HIV-negative cases of PEL, patients may be given liposomal anthracycline with or without bortezomib (proteasome inhibitor) and prednisone.

Bortezomib was reported to be efficacious in treating PEL cell lines when it was used alone or in combination with doxorubicin and Taxol [156]. Rapamycin has also shown promise in treating PEL cells in culture and in a xenograft model [157]. Although radiation therapy is rarely performed to treat PEL, it may be an option for patients who do not tolerate the above treatment options.

Treatment options for MCD include surgical excision, cytoreduction chemotherapy (CHOP or CVAD), radiation therapy, immune modulators such as steroids and interferon- $a$, thalidomide, monoclonal antibodies against IL-6 (atlizumab) and CD20 surface marker (rituximab), and inhibitors of KSHV viral replication (reviewed in [32; 158]). The patient responses to these therapeutic options are mixed and therefore, the establishment of treatment regimens requires more epidemiological data. As a general rule of thumb, chemotherapy is preferred for MCD with severe systemic symptoms; the viral replication inhibitors (especially ganciclovir), interferon-a, and anti-IL-6 and anti-CD20 monoclonal antibodies appear to be the more specific and promising candidates for treating MCD [158].

In conclusion, the current treatment strategies for KS, PEL, and MCD are still sub-optimal. While our understanding of KSHV biology and tumorigenesis has been increasing since the discovery of the virus, we are just beginning to translate knowledge from basic science research into more effective clinical management and therapies. We believe that the use of antiviral agents and small molecules that specifically target the signaling pathways of these 
tumor cells are potentially more efficacious and have fewer side effects than conventional chemotherapy regimens. More case reports and randomized clinical trials are needed to advance and standardize treatments for KSHV-associated malignancies.

\section{Acknowledgments}

Due to space restrictions we regret that we had to omit many important references. KWW is supported in part by NIAID training grant T32-AI007001 and MSTP grant T32-GM008719. BD is a Leukemia \& Lymphoma Society Scholar and a Burroughs Welcome Fund Investigator in Infectious Disease. Her work is supported by grants CA096500, DE18281, and HL083469 from the NIH.

\section{References}

1. Roizman B, Carmichael LE, Deinhardt F, de-The G, Nahmias AJ, Plowright W, Rapp F, Sheldrick P, Takahashi M, Wolf K. Herpesviridae. Definition, provisional nomenclature, and taxonomy. The Herpesvirus Study Group, the International Committee on Taxonomy of Viruses. Intervirology. 1981; 16:201-217. [PubMed: 7343541]

2. Young L, Alfieri C, Hennessy K, Evans H, O’Hara C, Anderson KC, Ritz J, Shapiro RS, Rickinson A, Kieff E, et al. Expression of Epstein-Barr virus transformation-associated genes in tissues of patients with EBV lymphoproliferative disease. N Engl J Med. 1989; 321:1080-1085. [PubMed: 2552313]

3. Raab-Traub N. Epstein-Barr virus in the pathogenesis of NPC. Semin Cancer Biol. 2002; 12:431441. [PubMed: 12450729]

4. Deacon EM, Pallesen G, Niedobitek G, Crocker J, Brooks L, Rickinson AB, Young LS. EpsteinBarr virus and Hodgkin's disease: transcriptional analysis of virus latency in the malignant cells. J Exp Med. 1993; 177:339-349. [PubMed: 8381153]

5. Kieff, E.; Rickinson, AB. Epstein-Barr virus and its replication. In: Knipe, DM., editor. Fields virology. Lippincott Williams \& Wilkins; Philadelphia, PA: 2001. p. 2511-2573.

6. Chang Y, Cesarman E, Pessin MS, Lee F, Culpepper J, Knowles DM, Moore PS. Identification of herpesvirus-like DNA sequences in AIDS-associated Kaposi's sarcoma. Science. 1994; 266:18651869. [PubMed: 7997879]

7. Neipel F, Fleckenstein B. The role of HHV-8 in Kaposi's sarcoma. Semin Cancer Biol. 1999; 9:151-164. [PubMed: 10343067]

8. Cesarman E, Chang Y, Moore PS, Said JW, Knowles DM. Kaposi's sarcoma-associated herpesvirus-like DNA sequences in AIDS-related body-cavity-based lymphomas. N Engl J Med. 1995; 332:1186-1191. [PubMed: 7700311]

9. Gessain A, Sudaka A, Briere J, Fouchard N, Nicola MA, Rio B, Arborio M, Troussard X, Audouin J, Diebold J, de The G. Kaposi sarcoma-associated herpes-like virus (human herpesvirus type 8) DNA sequences in multicentric Castleman disease: is there any relevant association in non-human immunodeficiency virus-infected patients? Blood. 1996; 87:414-416. [PubMed: 8547672]

10. Soulier J, Grollet L, Oksenhendler E, Cacoub P, Cazals-Hatem D, Babinet P, d'Agay MF, Clauvel JP, Raphael M, Degos L, et al. Kaposi's sarcoma-associated herpesvirus-like DNA sequences in multicentric Castleman disease. Blood. 1995; 86:1276-1280. [PubMed: 7632932]

11. Carbone A, Gloghini A, Vaccher E, Cerri M, Gaidano G, Dalla-Favera R, Tirelli U. Kaposi's sarcoma-associated herpesvirus/human herpesvirus type 8-positive solid lymphomas: a tissuebased variant of primary effusion lymphoma. J Mol Diagn. 2005; 7:17-27. [PubMed: 15681470]

12. Wheat WH, Cool CD, Morimoto Y, Rai PR, Kirkpatrick CH, Lindenbaum BA, Bates CA, Ellison MC, Serls AE, Brown KK, Routes JM. Possible role of human herpesvirus 8 in the lymphoproliferative disorders in common variable immunodeficiency. J Exp Med. 2005; 202:479_ 484. [PubMed: 16103407]

13. Kaposi M. Idiopathisches multiples Pigmentsarkom der Haut. Arch Dermatol Syph. 1872; 4:265273.

14. Wang HW, Trotter MW, Lagos D, Bourboulia D, Henderson S, Makinen T, Elliman S, Flanagan AM, Alitalo K, Boshoff C. Kaposi sarcoma herpesvirus-induced cellular reprogramming 
contributes to the lymphatic endothelial gene expression in Kaposi sarcoma. Nat Genet. 2004; 36:687-693. [PubMed: 15220918]

15. Beckstead JH, Wood GS, Fletcher V. Evidence for the origin of Kaposi's sarcoma from lymphatic endothelium. Am J Pathol. 1985; 119:294-300. [PubMed: 2986460]

16. Dupin N, Fisher C, Kellam P, Ariad S, Tulliez M, Franck N, van Marck E, Salmon D, Gorin I, Escande JP, Weiss RA, Alitalo K, Boshoff C. Distribution of human herpesvirus-8 latently infected cells in Kaposi's sarcoma, multicentric Castleman disease, and primary effusion lymphoma. Proc Natl Acad Sci U S A. 1999; 96:4546-4551. [PubMed: 10200299]

17. Gessain A, Duprez R. Spindle cells and their role in Kaposi's sarcoma. Int J Biochem Cell Biol. 2005; 37:2457-2465. [PubMed: 16188485]

18. Kyalwazi SK. Kaposi's sarcoma: clinical features, experience in Uganda. Antibiot Chemother. 1981; 29:59-69. [PubMed: 7294744]

19. Taylor JF, Templeton AC, Vogel CL, Ziegler JL, Kyalwazi SK. Kaposi's sarcoma in Uganda: a clinico-pathological study. Int J Cancer. 1971; 8:122-135. [PubMed: 5118203]

20. Friedman-Birnbaum R, Weltfriend S, Katz I. Kaposi's sarcoma: retrospective study of 67 cases with the classical form. Dermatologica. 1990; 180:13-17. [PubMed: 2307273]

21. Iscovich J, Boffetta P, Brennan P. Classic Kaposi's sarcoma as a first primary neoplasm. Int J Cancer. 1999; 80:173-177. [PubMed: 9935195]

22. Dutz W, Stout AP. Kaposi's sarcoma in infants and children. Cancer. 1960; 13:684-694. [PubMed: 13818924]

23. Biggar RJ, Rabkin CS. The epidemiology of AIDS--related neoplasms. Hematol Oncol Clin North Am. 1996; 10:997-1010. [PubMed: 8880192]

24. Beral V, Newton R. Overview of the epidemiology of immunodeficiency-associated cancers. J Natl Cancer Inst Monogr. 1998:1-6. [PubMed: 9709294]

25. Mbulaiteye SM, Biggar RJ, Goedert JJ, Engels EA. Immune deficiency and risk for malignancy among persons with AIDS. J Acquir Immune Defic Syndr. 2003; 32:527-533. [PubMed: 12679705]

26. Beral V, Peterman TA, Berkelman RL, Jaffe HW. Kaposi's sarcoma among persons with AIDS: a sexually transmitted infection? Lancet. 1990; 335:123-128. [PubMed: 1967430]

27. Wabinga HR, Parkin DM, Wabwire-Mangen F, Nambooze S. Trends in cancer incidence in Kyadondo County, Uganda, 1960-1997. Br J Cancer. 2000; 82:1585-1592. [PubMed: 10789729]

28. Echimane AK, Ahnoux AA, Adoubi I, Hien S, M'Bra K, D’Horpock A, Diomande M, Anongba D, Mensah-Adoh I, Parkin DM. Cancer incidence in Abidjan, Ivory Coast: first results from the cancer registry, 1995-1997. Cancer. 2000; 89:653-663. [PubMed: 10931466]

29. Parkin DM, Wabinga H, Nambooze S, Wabwire-Mangen F. AIDS-related cancers in Africa: maturation of the epidemic in Uganda. Aids. 1999; 13:2563-2570. [PubMed: 10630526]

30. Eltom MA, Jemal A, Mbulaiteye SM, Devesa SS, Biggar RJ. Trends in Kaposi's sarcoma and nonHodgkin's lymphoma incidence in the United States from 1973 through 1998. J Natl Cancer Inst. 2002; 94:1204-1210. [PubMed: 12189223]

31. Tam HK, Zhang ZF, Jacobson LP, Margolick JB, Chmiel JS, Rinaldo C, Detels R. Effect of highly active antiretroviral therapy on survival among HIV-infected men with Kaposi sarcoma or nonHodgkin lymphoma. Int J Cancer. 2002; 98:916-922. [PubMed: 11948473]

32. Casper C, Wald A. The use of antiviral drugs in the prevention and treatment of Kaposi sarcoma, multicentric Castleman disease and primary effusion lymphoma. Curr Top Microbiol Immunol. 2007; 312:289-307. [PubMed: 17089802]

33. Penn I. Secondary neoplasms as a consequence of transplantation and cancer therapy. Cancer Detect Prev. 1988; 12:39-57. [PubMed: 3052837]

34. Barozzi P, Luppi M, Facchetti F, Mecucci C, Alu M, Sarid R, Rasini V, Ravazzini L, Rossi E, Festa S, Crescenzi B, Wolf DG, Schulz TF, Torelli G. Post-transplant Kaposi sarcoma originates from the seeding of donor-derived progenitors. Nat Med. 2003; 9:554-561. [PubMed: 12692543]

35. Arvanitakis L, Mesri EA, Nador RG, Said JW, Asch AS, Knowles DM, Cesarman E. Establishment and characterization of a primary effusion (body cavity-based) lymphoma cell line (BC-3) harboring kaposi's sarcoma-associated herpesvirus (KSHV/HHV-8) in the absence of Epstein-Barr virus. Blood. 1996; 88:2648-2654. [PubMed: 8839859] 
36. Komanduri KV, Luce JA, McGrath MS, Herndier BG, Ng VL. The natural history and molecular heterogeneity of HIV-associated primary malignant lymphomatous effusions. J Acquir Immune Defic Syndr Hum Retrovirol. 1996; 13:215-226. [PubMed: 8898666]

37. Nador RG, Cesarman E, Chadburn A, Dawson DB, Ansari MQ, Sald J, Knowles DM. Primary effusion lymphoma: a distinct clinicopathologic entity associated with the Kaposi's sarcomaassociated herpes virus. Blood. 1996; 88:645-656. [PubMed: 8695812]

38. Renne R, Lagunoff M, Zhong W, Ganem D. The size and conformation of Kaposi's sarcomaassociated herpesvirus (human herpesvirus 8) DNA in infected cells and virions. J Virol. 1996; 70:8151-8154. [PubMed: 8892944]

39. Staudt MR, Kanan Y, Jeong JH, Papin JF, Hines-Boykin R, Dittmer DP. The tumor microenvironment controls primary effusion lymphoma growth in vivo. Cancer Res. 2004; 64:4790-4799. [PubMed: 15256448]

40. Radaszkiewicz T, Hansmann ML, Lennert K. Monoclonality and polyclonality of plasma cells in Castleman disease of the plasma cell variant. Histopathology. 1989; 14:11-24. [PubMed: 2925176]

41. Hall PA, Donaghy M, Cotter FE, Stansfeld AG, Levison DA. An immunohistological and genotypic study of the plasma cell form of Castleman disease. Histopathology. 1989; 14:333-346. discussion 429-332. [PubMed: 2737612]

42. Parravicini C, Corbellino M, Paulli M, Magrini U, Lazzarino M, Moore PS, Chang Y. Expression of a virus-derived cytokine, KSHV vIL-6, in HIV-seronegative Castleman disease. Am J Pathol. 1997; 151:1517-1522. [PubMed: 9403701]

43. Renne R, Zhong W, Herndier B, McGrath M, Abbey N, Kedes D, Ganem D. Lytic growth of Kaposi's sarcoma-associated herpesvirus (human herpesvirus 8) in culture. Nat Med. 1996; 2:342346. [PubMed: 8612236]

44. Neipel F, Albrecht JC, Fleckenstein B. Human herpesvirus 8--the first human Rhadinovirus. J Natl Cancer Inst Monogr. 1998:73-77. [PubMed: 9709307]

45. Duprez R, Lacoste V, Briere J, Couppie P, Frances C, Sainte-Marie D, Kassa-Kelembho E, Lando MJ, Essame Oyono JL, Nkegoum B, Hbid O, Mahe A, Lebbe C, Tortevoye P, Huerre M, Gessain A. Evidence for a multiclonal origin of multicentric advanced lesions of Kaposi sarcoma. J Natl Cancer Inst. 2007; 99:1086-1094. [PubMed: 17623796]

46. Swanton C, Mann DJ, Fleckenstein B, Neipel F, Peters G, Jones N. Herpes viral cyclin/Cdk6 complexes evade inhibition by CDK inhibitor proteins. Nature. 1997; 390:184-187. [PubMed: 9367157]

47. Schulz, TF.; Chang, Y. KSHV gene expression and regulation. In: Arvin, AM.; Campadelli-Fiume, G.; Mocarski, E.; Moore, PS.; Roizman, B.; Whitley, RS., editors. Human Herpesviruses: Biology, Therapy, And Immunoprophylaxis. Cambridge; Great Britain/British Isles: 2007. p. 490-513.

48. Lin SF, Robinson DR, Miller G, Kung HJ. Kaposi's sarcoma-associated herpesvirus encodes a bZIP protein with homology to BZLF1 of Epstein-Barr virus. J Virol. 1999; 73:1909-1917. [PubMed: 9971770]

49. Low W, Harries M, Ye H, Du MQ, Boshoff C, Collins M. Internal ribosome entry site regulates translation of Kaposi's sarcoma-associated herpesvirus FLICE inhibitory protein. J Virol. 2001; 75:2938-2945. [PubMed: 11222719]

50. Pearce M, Matsumura S, Wilson AC. Transcripts encoding K12, v-FLIP, v-cyclin, and the microRNA cluster of Kaposi's sarcoma-associated herpesvirus originate from a common promoter. J Virol. 2005; 79:14457-14464. [PubMed: 16254382]

51. Samols MA, Hu J, Skalsky RL, Renne R. Cloning and identification of a microRNA cluster within the latency-associated region of Kaposi's sarcoma-associated herpesvirus. J Virol. 2005; 79:93019305. [PubMed: 15994824]

52. Cai X, Lu S, Zhang Z, Gonzalez CM, Damania B, Cullen BR. Kaposi's sarcoma-associated herpesvirus expresses an array of viral microRNAs in latently infected cells. Proc Natl Acad Sci U S A. 2005; 102:5570-5575. [PubMed: 15800047]

53. Pfeffer S, Sewer A, Lagos-Quintana M, Sheridan R, Sander C, Grasser FA, van Dyk LF, Ho CK, Shuman S, Chien M, Russo JJ, Ju J, Randall G, Lindenbach BD, Rice CM, Simon V, Ho DD, 
Zavolan M, Tuschl T. Identification of microRNAs of the herpesvirus family. Nat Methods. 2005; 2:269-276. [PubMed: 15782219]

54. Murphy E, Vanicek J, Robins H, Shenk T, Levine AJ. Suppression of immediate-early viral gene expression by herpesvirus-coded microRNAs: implications for latency. Proc Natl Acad Sci U S A. 2008; 105:5453-5458. [PubMed: 18378902]

55. Samols MA, Skalsky RL, Maldonado AM, Riva A, Lopez MC, Baker HV, Renne R. Identification of cellular genes targeted by KSHV-encoded microRNAs. PLoS Pathog. 2007; 3:e65. [PubMed: 17500590]

56. Cai X, Cullen BR. Transcriptional origin of Kaposi's sarcoma-associated herpesvirus microRNAs. J Virol. 2006; 80:2234-2242. [PubMed: 16474131]

57. Gottwein E, Mukherjee N, Sachse C, Frenzel C, Majoros WH, Chi JT, Braich R, Manoharan M, Soutschek J, Ohler U, Cullen BR. A viral microRNA functions as an orthologue of cellular miR-155. Nature. 2007; 450:1096-1099. [PubMed: 18075594]

58. Skalsky RL, Samols MA, Plaisance KB, Boss IW, Riva A, Lopez MC, Baker HV, Renne R. Kaposi's sarcoma-associated herpesvirus encodes an ortholog of miR-155. J Virol. 2007; 81:12836-12845. [PubMed: 17881434]

59. Marshall V, Parks T, Bagni R, Wang CD, Samols MA, Hu J, Wyvil KM, Aleman K, Little RF, Yarchoan R, Renne R, Whitby D. Conservation of virally encoded microRNAs in Kaposi sarcoma--associated herpesvirus in primary effusion lymphoma cell lines and in patients with Kaposi sarcoma or multicentric Castleman disease. J Infect Dis. 2007; 195:645-659. [PubMed: 17262705]

60. Conrad NK, Fok V, Cazalla D, Borah S, Steitz JA. The challenge of viral snRNPs. Cold Spring Harb Symp Quant Biol. 2006; 71:377-384. [PubMed: 17381320]

61. Conrad NK, Steitz JA. A Kaposi's sarcoma virus RNA element that increases the nuclear abundance of intronless transcripts. Embo J. 2005; 24:1831-1841. [PubMed: 15861127]

62. Sun R, Lin SF, Gradoville L, Miller G. Polyadenylylated nuclear RNA encoded by Kaposi sarcoma-associated herpesvirus. Proc Natl Acad Sci U S A. 1996; 93:11883-11888. [PubMed: 8876232]

63. Zhong W, Ganem D. Characterization of ribonucleoprotein complexes containing an abundant polyadenylated nuclear RNA encoded by Kaposi's sarcoma-associated herpesvirus (human herpesvirus 8). J Virol. 1997; 71:1207-1212. [PubMed: 8995643]

64. Parravicini C, Chandran B, Corbellino M, Berti E, Paulli M, Moore PS, Chang Y. Differential viral protein expression in Kaposi's sarcoma-associated herpesvirus-infected diseases: Kaposi's sarcoma, primary effusion lymphoma, and multicentric Castleman disease. Am J Pathol. 2000; 156:743-749. [PubMed: 10702388]

65. Dittmer DP. Transcription profile of Kaposi's sarcoma-associated herpesvirus in primary Kaposi's sarcoma lesions as determined by real-time PCR arrays. Cancer Res. 2003; 63:2010-2015. [PubMed: 12727810]

66. Fakhari FD, Dittmer DP. Charting latency transcripts in Kaposi's sarcoma-associated herpesvirus by whole-genome real-time quantitative PCR. J Virol. 2002; 76:6213-6223. [PubMed: 12021355]

67. Jenner RG, Alba MM, Boshoff C, Kellam P. Kaposi's sarcoma-associated herpesvirus latent and lytic gene expression as revealed by DNA arrays. J Virol. 2001; 75:891-902. [PubMed: 11134302]

68. Paulose-Murphy M, Ha NK, Xiang C, Chen Y, Gillim L, Yarchoan R, Meltzer P, Bittner M, Trent J, Zeichner S. Transcription program of human herpesvirus 8 (kaposi's sarcoma-associated herpesvirus). J Virol. 2001; 75:4843-4853. [PubMed: 11312356]

69. Rossetto C, Gao Y, Yamboliev I, Papouskova I, Pari G. Transcriptional repression of K-Rta by Kaposi's sarcoma-associated herpesvirus K-bZIP is not required for oriLyt-dependent DNA replication. Virology. 2007; 369:340-350. [PubMed: 17889220]

70. Izumiya Y, Ellison TJ, Yeh ET, Jung JU, Luciw PA, Kung HJ. Kaposi’s sarcoma-associated herpesvirus K-bZIP represses gene transcription via SUMO modification. J Virol. 2005; 79:99129925. [PubMed: 16014952]

71. Zhu FX, King SM, Smith EJ, Levy DE, Yuan Y. A Kaposi's sarcoma-associated herpesviral protein inhibits virus-mediated induction of type I interferon by blocking IRF-7 phosphorylation and nuclear accumulation. Proc Natl Acad Sci U S A. 2002; 99:5573-5578. [PubMed: 11943871] 
72. Miller G, Heston L, Grogan E, Gradoville L, Rigsby M, Sun R, Shedd D, Kushnaryov VM, Grossberg S, Chang Y. Selective switch between latency and lytic replication of Kaposi's sarcoma herpesvirus and Epstein-Barr virus in dually infected body cavity lymphoma cells. J Virol. 1997; 71:314-324. [PubMed: 8985352]

73. Pan H, Zhou F, Gao SJ. Kaposi's sarcoma-associated herpesvirus induction of chromosome instability in primary human endothelial cells. Cancer Res. 2004; 64:4064-4068. [PubMed: 15205312]

74. Poole LJ, Yu Y, Kim PS, Zheng QZ, Pevsner J, Hayward GS. Altered patterns of cellular gene expression in dermal microvascular endothelial cells infected with Kaposi's sarcoma-associated herpesvirus. J Virol. 2002; 76:3395-3420. [PubMed: 11884566]

75. Flore O, Rafii S, Ely S, O’Leary JJ, Hyjek EM, Cesarman E. Transformation of primary human endothelial cells by Kaposi's sarcoma-associated herpesvirus. Nature. 1998; 394:588-592. [PubMed: 9707121]

76. Qian LW, Xie J, Ye F, Gao SJ. Kaposi’s sarcoma-associated herpesvirus infection promotes invasion of primary human umbilical vein endothelial cells by inducing matrix metalloproteinases. J Virol. 2007; 81:7001-7010. [PubMed: 17442715]

77. Wang L, Damania B. Kaposi's sarcoma-associated herpesvirus confers a survival advantage to endothelial cells. Cancer Res. 2008; 68:4640-4648. [PubMed: 18559509]

78. Dittmer, D. KSHV viral latent lifecycle. In: Damania, B.; Pipas, J., editors. DNA Tumor Viruses. Springer; 2008.

79. Verma SC, Lan K, Robertson E. Structure and function of latency-associated nuclear antigen. Curr Top Microbiol Immunol. 2007; 312:101-136. [PubMed: 17089795]

80. Rainbow L, Platt GM, Simpson GR, Sarid R, Gao SJ, Stoiber H, Herrington CS, Moore PS, Schulz TF. The 222- to 234-kilodalton latent nuclear protein (LNA) of Kaposi's sarcoma-associated herpesvirus (human herpesvirus 8) is encoded by orf73 and is a component of the latencyassociated nuclear antigen. J Virol. 1997; 71:5915-5921. [PubMed: 9223481]

81. Friborg J Jr, Kong W, Hottiger MO, Nabel GJ. p53 inhibition by the LANA protein of KSHV protects against cell death. Nature. 1999; 402:889-894. [PubMed: 10622254]

82. Radkov SA, Kellam P, Boshoff C. The latent nuclear antigen of Kaposi sarcoma-associated herpesvirus targets the retinoblastoma-E2F pathway and with the oncogene Hras transforms primary rat cells. Nat Med. 2000; 6:1121-1127. [PubMed: 11017143]

83. Denis GV, Vaziri C, Guo N, Faller DV. RING3 kinase transactivates promoters of cell cycle regulatory genes through E2F. Cell Growth Differ. 2000; 11:417-424. [PubMed: 10965846]

84. Guo N, Faller DV, Denis GV. Activation-induced nuclear translocation of RING3. J Cell Sci. 2000; 113(Pt 17):3085-3091. [PubMed: 10934046]

85. Viejo-Borbolla A, Ottinger M, Bruning E, Burger A, Konig R, Kati E, Sheldon JA, Schulz TF. Brd2/RING3 interacts with a chromatin-binding domain in the Kaposi's Sarcoma-associated herpesvirus latency-associated nuclear antigen 1 (LANA-1) that is required for multiple functions of LANA-1. J Virol. 2005; 79:13618-13629. [PubMed: 16227282]

86. Platt GM, Simpson GR, Mittnacht S, Schulz TF. Latent nuclear antigen of Kaposi's sarcomaassociated herpesvirus interacts with RING3, a homolog of the Drosophila female sterile homeotic (fsh) gene. J Virol. 1999; 73:9789-9795. [PubMed: 10559289]

87. Fujimuro M, Hayward SD. The latency-associated nuclear antigen of Kaposi's sarcoma-associated herpesvirus manipulates the activity of glycogen synthase kinase-3beta. J Virol. 2003; 77:80198030. [PubMed: 12829841]

88. Boshoff C. Kaposi virus scores cancer coup. Nat Med. 2003; 9:261-262. [PubMed: 12612569]

89. Watanabe T, Sugaya M, Atkins AM, Aquilino EA, Yang A, Borris DL, Brady J, Blauvelt A. Kaposi's sarcoma-associated herpesvirus latency-associated nuclear antigen prolongs the life span of primary human umbilical vein endothelial cells. J Virol. 2003; 77:6188-6196. [PubMed: 12743275]

90. Fakhari FD, Jeong JH, Kanan Y, Dittmer DP. The latency-associated nuclear antigen of Kaposi sarcoma-associated herpesvirus induces B cell hyperplasia and lymphoma. J Clin Invest. 2006; 116:735-742. [PubMed: 16498502] 
91. Dittmer D, Lagunoff M, Renne R, Staskus K, Haase A, Ganem D. A cluster of latently expressed genes in Kaposi's sarcoma-associated herpesvirus. J Virol. 1998; 72:8309-8315. [PubMed: 9733875]

92. Grundhoff A, Ganem D. Mechanisms governing expression of the v-FLIP gene of Kaposi's sarcoma-associated herpesvirus. J Virol. 2001; 75:1857-1863. [PubMed: 11160684]

93. Bieleski L, Talbot SJ. Kaposi's sarcoma-associated herpesvirus vCyclin open reading frame contains an internal ribosome entry site. J Virol. 2001; 75:1864-1869. [PubMed: 11160685]

94. Belanger C, Gravel A, Tomoiu A, Janelle ME, Gosselin J, Tremblay MJ, Flamand L. Human herpesvirus 8 viral FLICE-inhibitory protein inhibits Fas-mediated apoptosis through binding and prevention of procaspase-8 maturation. J Hum Virol. 2001; 4:62-73. [PubMed: 11437316]

95. Djerbi M, Screpanti V, Catrina AI, Bogen B, Biberfeld P, Grandien A. The inhibitor of death receptor signaling, FLICE-inhibitory protein defines a new class of tumor progression factors. $\mathbf{J}$ Exp Med. 1999; 190:1025-1032. [PubMed: 10510092]

96. Liu L, Eby MT, Rathore N, Sinha SK, Kumar A, Chaudhary PM. The human herpes virus 8encoded viral FLICE inhibitory protein physically associates with and persistently activates the Ikappa B kinase complex. J Biol Chem. 2002; 277:13745-13751. [PubMed: 11830587]

97. Field N, Low W, Daniels M, Howell S, Daviet L, Boshoff C, Collins M. KSHV vFLIP binds to IKK-gamma to activate IKK. J Cell Sci. 2003; 116:3721-3728. [PubMed: 12890756]

98. Chaudhary PM, Jasmin A, Eby MT, Hood L. Modulation of the NF-kappa B pathway by virally encoded death effector domains-containing proteins. Oncogene. 1999; 18:5738-5746. [PubMed: 10523854]

99. Bubman D, Guasparri I, Cesarman E. Deregulation of c-Myc in primary effusion lymphoma by Kaposi's sarcoma herpesvirus latency-associated nuclear antigen. Oncogene. 2007; 26:4979-4986. [PubMed: 17310999]

100. Ye FC, Zhou FC, Xie JP, Kang T, Greene W, Kuhne K, Lei XF, Li QH, Gao SJ. Kaposi's sarcoma-associated herpesvirus latent gene vFLIP inhibits viral lytic replication through NFkappaB-mediated suppression of the AP-1 pathway: a novel mechanism of virus control of latency. J Virol. 2008; 82:4235-4249. [PubMed: 18305042]

101. Zhao J, Punj V, Matta H, Mazzacurati L, Schamus S, Yang Y, Yang T, Hong Y, Chaudhary PM. K13 blocks KSHV lytic replication and deregulates vIL6 and hIL6 expression: a model of lytic replication induced clonal selection in viral oncogenesis. PLoS ONE. 2007; 2:e1067. [PubMed: 17957251]

102. Sun Q, Zachariah S, Chaudhary PM. The human herpes virus 8-encoded viral FLICE-inhibitory protein induces cellular transformation via NF-kappaB activation. J Biol Chem. 2003; 278:52437-52445. [PubMed: 14563855]

103. Efklidou S, Bailey R, Field N, Noursadeghi M, Collins MK. vFLIP from KSHV inhibits anoikis of primary endothelial cells. J Cell Sci. 2008; 121:450-457. [PubMed: 18211958]

104. Sadler R, Wu L, Forghani B, Renne R, Zhong W, Herndier B, Ganem D. A complex translational program generates multiple novel proteins from the latently expressed kaposin (K12) locus of Kaposi's sarcoma-associated herpesvirus. J Virol. 1999; 73:5722-5730. [PubMed: 10364323]

105. Kliche S, Nagel W, Kremmer E, Atzler C, Ege A, Knorr T, Koszinowski U, Kolanus W, Haas J. Signaling by human herpesvirus 8 kaposin A through direct membrane recruitment of cytohesin-1. Mol Cell. 2001; 7:833-843. [PubMed: 11336706]

106. Muralidhar S, Pumfery AM, Hassani M, Sadaie MR, Kishishita M, Brady JN, Doniger J, Medveczky P, Rosenthal LJ. Identification of kaposin (open reading frame K12) as a human herpesvirus 8 (Kaposi's sarcoma-associated herpesvirus) transforming gene. J Virol. 1998; 72:4980-4988. [PubMed: 9573267]

107. McCormick C, Ganem D. The kaposin B protein of KSHV activates the p38/MK2 pathway and stabilizes cytokine mRNAs. Science. 2005; 307:739-741. [PubMed: 15692053]

108. McCormick C, Ganem D. Phosphorylation and function of the kaposin B direct repeats of Kaposi's sarcoma-associated herpesvirus. J Virol. 2006; 80:6165-6170. [PubMed: 16731955]

109. Lagunoff M, Ganem D. The structure and coding organization of the genomic termini of Kaposi's sarcoma-associated herpesvirus. Virology. 1997; 236:147-154. [PubMed: 9299627] 
110. Lee H, Guo J, Li M, Choi JK, DeMaria M, Rosenzweig M, Jung JU. Identification of an immunoreceptor tyrosine-based activation motif of K1 transforming protein of Kaposi's sarcoma-associated herpesvirus. Mol Cell Biol. 1998; 18:5219-5228. [PubMed: 9710606]

111. Wang L, Dittmer DP, Tomlinson CC, Fakhari FD, Damania B. Immortalization of primary endothelial cells by the K1 protein of Kaposi's sarcoma-associated herpesvirus. Cancer Res. 2006; 66:3658-3666. [PubMed: 16585191]

112. Lee BS, Connole M, Tang Z, Harris NL, Jung JU. Structural analysis of the Kaposi's sarcomaassociated herpesvirus K1 protein. J Virol. 2003; 77:8072-8086. [PubMed: 12829846]

113. Lee H, Veazey R, Williams K, Li M, Guo J, Neipel F, Fleckenstein B, Lackner A, Desrosiers RC, Jung JU. Deregulation of cell growth by the K1 gene of Kaposi's sarcoma-associated herpesvirus. Nat Med. 1998; 4:435-440. [PubMed: 9546789]

114. Prakash O, Tang ZY, Peng X, Coleman R, Gill J, Farr G, Samaniego F. Tumorigenesis and aberrant signaling in transgenic mice expressing the human herpesvirus- $8 \mathrm{~K} 1$ gene. J Natl Cancer Inst. 2002; 94:926-935. [PubMed: 12072546]

115. Tomlinson CC, Damania B. The K1 protein of Kaposi's sarcoma-associated herpesvirus activates the Akt signaling pathway. J Virol. 2004; 78:1918-1927. [PubMed: 14747556]

116. Lagunoff M, Majeti R, Weiss A, Ganem D. Deregulated signal transduction by the K1 gene product of Kaposi's sarcoma-associated herpesvirus. Proc Natl Acad Sci U S A. 1999; 96:57045709. [PubMed: 10318948]

117. Lee BS, Alvarez X, Ishido S, Lackner AA, Jung JU. Inhibition of intracellular transport of B cell antigen receptor complexes by Kaposi's sarcoma-associated herpesvirus K1. J Exp Med. 2000; 192:11-21. [PubMed: 10880522]

118. Tomlinson CC, Damania B. Critical role for endocytosis in the regulation of signaling by the Kaposi's sarcoma-associated herpesvirus K1 protein. J Virol. 2008; 82:6514-6523. [PubMed: 18434405]

119. Wang L, Wakisaka N, Tomlinson CC, DeWire SM, Krall S, Pagano JS, Damania B. The Kaposi's sarcoma-associated herpesvirus (KSHV/HHV-8) K1 protein induces expression of angiogenic and invasion factors. Cancer Res. 2004; 64:2774-2781. [PubMed: 15087393]

120. Guo HG, Browning P, Nicholas J, Hayward GS, Tschachler E, Jiang YW, Sadowska M, Raffeld M, Colombini S, Gallo RC, Reitz MS Jr. Characterization of a chemokine receptor-related gene in human herpesvirus 8 and its expression in Kaposi's sarcoma. Virology. 1997; 228:371-378. [PubMed: 9123844]

121. Arvanitakis L, Geras-Raaka E, Varma A, Gershengorn MC, Cesarman E. Human herpesvirus KSHV encodes a constitutively active G-protein-coupled receptor linked to cell proliferation. Nature. 1997; 385:347-350. [PubMed: 9002520]

122. Cesarman E, Nador RG, Bai F, Bohenzky RA, Russo JJ, Moore PS, Chang Y, Knowles DM. Kaposi's sarcoma-associated herpesvirus contains G protein-coupled receptor and cyclin D homologs which are expressed in Kaposi's sarcoma and malignant lymphoma. J Virol. 1996; 70:8218-8223. [PubMed: 8892957]

123. Sodhi A, Montaner S, Patel V, Zohar M, Bais C, Mesri EA, Gutkind JS. The Kaposi's sarcomaassociated herpes virus $\mathrm{G}$ protein-coupled receptor up-regulates vascular endothelial growth factor expression and secretion through mitogen-activated protein kinase and p38 pathways acting on hypoxia-inducible factor 1alpha. Cancer Res. 2000; 60:4873-4880. [PubMed: 10987301]

124. Bais C, Santomasso B, Coso O, Arvanitakis L, Raaka EG, Gutkind JS, Asch AS, Cesarman E, Gershengorn MC, Mesri EA. G-protein-coupled receptor of Kaposi's sarcoma-associated herpesvirus is a viral oncogene and angiogenesis activator. Nature. 1998; 391:86-89. [PubMed: 9422510]

125. Montaner S, Sodhi A, Pece S, Mesri EA, Gutkind JS. The Kaposi's sarcoma-associated herpesvirus $\mathrm{G}$ protein-coupled receptor promotes endothelial cell survival through the activation of Akt/protein kinase B. Cancer Res. 2001; 61:2641-2648. [PubMed: 11289142]

126. Bais C, Van Geelen A, Eroles P, Mutlu A, Chiozzini C, Dias S, Silverstein RL, Rafii S, Mesri EA. Kaposi's sarcoma associated herpesvirus G protein-coupled receptor immortalizes human 
endothelial cells by activation of the VEGF receptor-2/KDR. Cancer Cell. 2003; 3:131-143. [PubMed: 12620408]

127. Guo HG, Sadowska M, Reid W, Tschachler E, Hayward G, Reitz M. Kaposi's sarcoma-like tumors in a human herpesvirus 8 ORF74 transgenic mouse. J Virol. 2003; 77:2631-2639. [PubMed: 12552002]

128. Montaner S, Sodhi A, Molinolo A, Bugge TH, Sawai ET, He Y, Li Y, Ray PE, Gutkind JS. Endothelial infection with KSHV genes in vivo reveals that vGPCR initiates Kaposi's sarcomagenesis and can promote the tumorigenic potential of viral latent genes. Cancer Cell. 2003; 3:23-36. [PubMed: 12559173]

129. Yang TY, Chen SC, Leach MW, Manfra D, Homey B, Wiekowski M, Sullivan L, Jenh CH, Narula SK, Chensue SW, Lira SA. Transgenic expression of the chemokine receptor encoded by human herpesvirus 8 induces an angioproliferative disease resembling Kaposi's sarcoma. J Exp Med. 2000; 191:445-454. [PubMed: 10662790]

130. Rosenkilde MM, Kledal TN, Brauner-Osborne H, Schwartz TW. Agonists and inverse agonists for the herpesvirus 8-encoded constitutively active seven-transmembrane oncogene product, ORF-74. J Biol Chem. 1999; 274:956-961. [PubMed: 9873037]

131. Staskus KA, Sun R, Miller G, Racz P, Jaslowski A, Metroka C, Brett-Smith H, Haase AT. Cellular tropism and viral interleukin-6 expression distinguish human herpesvirus 8 involvement in Kaposi's sarcoma, primary effusion lymphoma, and multicentric Castleman disease. J Virol. 1999; 73:4181-4187. [PubMed: 10196314]

132. Miles SA, Rezai AR, Salazar-Gonzalez JF, Vander Meyden M, Stevens RH, Logan DM, Mitsuyasu RT, Taga T, Hirano T, Kishimoto T, et al. AIDS Kaposi sarcoma-derived cells produce and respond to interleukin 6. Proc Natl Acad Sci U S A. 1990; 87:4068-4072. [PubMed: 1693429]

133. Yoshizaki K, Matsuda T, Nishimoto N, Kuritani T, Taeho L, Aozasa K, Nakahata T, Kawai H, Tagoh H, Komori T, et al. Pathogenic significance of interleukin-6 (IL-6/BSF-2) in Castleman disease. Blood. 1989; 74:1360-1367. [PubMed: 2788466]

134. Molden J, Chang Y, You Y, Moore PS, Goldsmith MA. A Kaposi's sarcoma-associated herpesvirus-encoded cytokine homolog (vIL-6) activates signaling through the shared gp130 receptor subunit. J Biol Chem. 1997; 272:19625-19631. [PubMed: 9235971]

135. Osborne J, Moore PS, Chang Y. KSHV-encoded viral IL-6 activates multiple human IL-6 signaling pathways. Hum Immunol. 1999; 60:921-927. [PubMed: 10566591]

136. Liu C, Okruzhnov Y, Li H, Nicholas J. Human herpesvirus 8 (HHV-8)-encoded cytokines induce expression of and autocrine signaling by vascular endothelial growth factor (VEGF) in HHV-8infected primary-effusion lymphoma cell lines and mediate VEGF-independent antiapoptotic effects. J Virol. 2001; 75:10933-10940. [PubMed: 11602733]

137. Aoki Y, Jaffe ES, Chang Y, Jones K, Teruya-Feldstein J, Moore PS, Tosato G. Angiogenesis and hematopoiesis induced by Kaposi's sarcoma-associated herpesvirus-encoded interleukin-6. Blood. 1999; 93:4034-4043. [PubMed: 10361100]

138. Russo JJ, Bohenzky RA, Chien MC, Chen J, Yan M, Maddalena D, Parry JP, Peruzzi D, Edelman IS, Chang Y, Moore PS. Nucleotide sequence of the Kaposi sarcoma-associated herpesvirus (HHV8). Proc Natl Acad Sci U S A. 1996; 93:14862-14867. [PubMed: 8962146]

139. Li M, Lee H, Guo J, Neipel F, Fleckenstein B, Ozato K, Jung JU. Kaposi's sarcoma-associated herpesvirus viral interferon regulatory factor. J Virol. 1998; 72:5433-5440. [PubMed: 9620998]

140. Pozharskaya VP, Weakland LL, Zimring JC, Krug LT, Unger ER, Neisch A, Joshi H, Inoue N, Offermann MK. Short duration of elevated vIRF-1 expression during lytic replication of human herpesvirus 8 limits its ability to block antiviral responses induced by alpha interferon in BCBL-1 cells. J Virol. 2004; 78:6621-6635. [PubMed: 15163753]

141. Burysek L, Yeow WS, Lubyova B, Kellum M, Schafer SL, Huang YQ, Pitha PM. Functional analysis of human herpesvirus 8-encoded viral interferon regulatory factor 1 and its association with cellular interferon regulatory factors and p300. J Virol. 1999; 73:7334-7342. [PubMed: 10438822] 
142. Gao SJ, Boshoff C, Jayachandra S, Weiss RA, Chang Y, Moore PS. KSHV ORF K9 (vIRF) is an oncogene which inhibits the interferon signaling pathway. Oncogene. 1997; 15:1979-1985. [PubMed: 9365244]

143. Lin R, Genin P, Mamane Y, Sgarbanti M, Battistini A, Harrington WJ Jr, Barber GN, Hiscott J. HHV-8 encoded vIRF-1 represses the interferon antiviral response by blocking IRF-3 recruitment of the CBP/p300 coactivators. Oncogene. 2001; 20:800-811. [PubMed: 11314014]

144. Seo T, Park J, Lee D, Hwang SG, Choe J. Viral interferon regulatory factor 1 of Kaposi's sarcoma-associated herpesvirus binds to $\mathrm{p} 53$ and represses p53-dependent transcription and apoptosis. J Virol. 2001; 75:6193-6198. [PubMed: 11390621]

145. Nakamura H, Li M, Zarycki J, Jung JU. Inhibition of p53 tumor suppressor by viral interferon regulatory factor. J Virol. 2001; 75:7572-7582. [PubMed: 11462029]

146. Jayachandra S, Low KG, Thlick AE, Yu J, Ling PD, Chang Y, Moore PS. Three unrelated viral transforming proteins (vIRF, EBNA2, and E1A) induce the MYC oncogene through the interferon-responsive PRF element by using different transcription coadaptors. Proc Natl Acad Sci U S A. 1999; 96:11566-11571. [PubMed: 10500217]

147. Katano H, Sato Y, Kurata T, Mori S, Sata T. Expression and localization of human herpesvirus 8encoded proteins in primary effusion lymphoma, Kaposi's sarcoma, and multicentric Castleman disease. Virology. 2000; 269:335-344. [PubMed: 10753712]

148. Katano H, Sata T. Human herpesvirus 8 virology, epidemiology and related diseases. Jpn J Infect Dis. 2000; 53:137-155. [PubMed: 11056556]

149. Stallone G, Infante B, Grandaliano G, Schena FP, Gesualdo L. Kaposi's sarcoma and mTOR: a crossroad between viral infection neoangiogenesis and immunosuppression. Transpl Int. 2008; 21:825-832. [PubMed: 18498314]

150. Stallone G, Schena A, Infante B, Di Paolo S, Loverre A, Maggio G, Ranieri E, Gesualdo L, Schena FP, Grandaliano G. Sirolimus for Kaposi's sarcoma in renal-transplant recipients. N Engl J Med. 2005; 352:1317-1323. [PubMed: 15800227]

151. Little RF, Aleman K, Kumar P, Wyvill KM, Pluda JM, Read-Connole E, Wang V, Pittaluga S, Catanzaro AT, Steinberg SM, Yarchoan R. Phase 2 study of pegylated liposomal doxorubicin in combination with interleukin-12 for AIDS-related Kaposi sarcoma. Blood. 2007; 110:41654171. [PubMed: 17846226]

152. Koon HB, Bubley GJ, Pantanowitz L, Masiello D, Smith B, Crosby K, Proper J, Weeden W, Miller TE, Chatis P, Egorin MJ, Tahan SR, Dezube BJ. Imatinib-induced regression of AIDSrelated Kaposi's sarcoma. J Clin Oncol. 2005; 23:982-989. [PubMed: 15572730]

153. Oksenhendler E, Clauvel JP, Jouveshomme S, Davi F, Mansour G. Complete remission of a primary effusion lymphoma with antiretroviral therapy. Am J Hematol. 1998; 57:266. [PubMed: 9495391]

154. Simonelli C, Spina M, Cinelli R, Talamini R, Tedeschi R, Gloghini A, Vaccher E, Carbone A, Tirelli U. Clinical features and outcome of primary effusion lymphoma in HIV-infected patients: a single-institution study. J Clin Oncol. 2003; 21:3948-3954. [PubMed: 14581418]

155. Hocqueloux L, Agbalika F, Oksenhendler E, Molina JM. Long-term remission of an AIDSrelated primary effusion lymphoma with antiviral therapy. Aids. 2001; 15:280-282. [PubMed: 11216942]

156. An J, Sun Y, Fisher M, Rettig MB. Antitumor effects of bortezomib (PS-341) on primary effusion lymphomas. Leukemia. 2004; 18:1699-1704. [PubMed: 15343345]

157. Sin SH, Roy D, Wang L, Staudt MR, Fakhari FD, Patel DD, Henry D, Harrington WJ Jr, Damania BA, Dittmer DP. Rapamycin is efficacious against primary effusion lymphoma (PEL) cell lines in vivo by inhibiting autocrine signaling. Blood. 2007; 109:2165-2173. [PubMed: 17082322]

158. Casper $\mathrm{C}$. The aetiology and management of Castleman disease at 50 years: translating pathophysiology to patient care. Br J Haematol. 2005; 129:3-17. [PubMed: 15801951] 


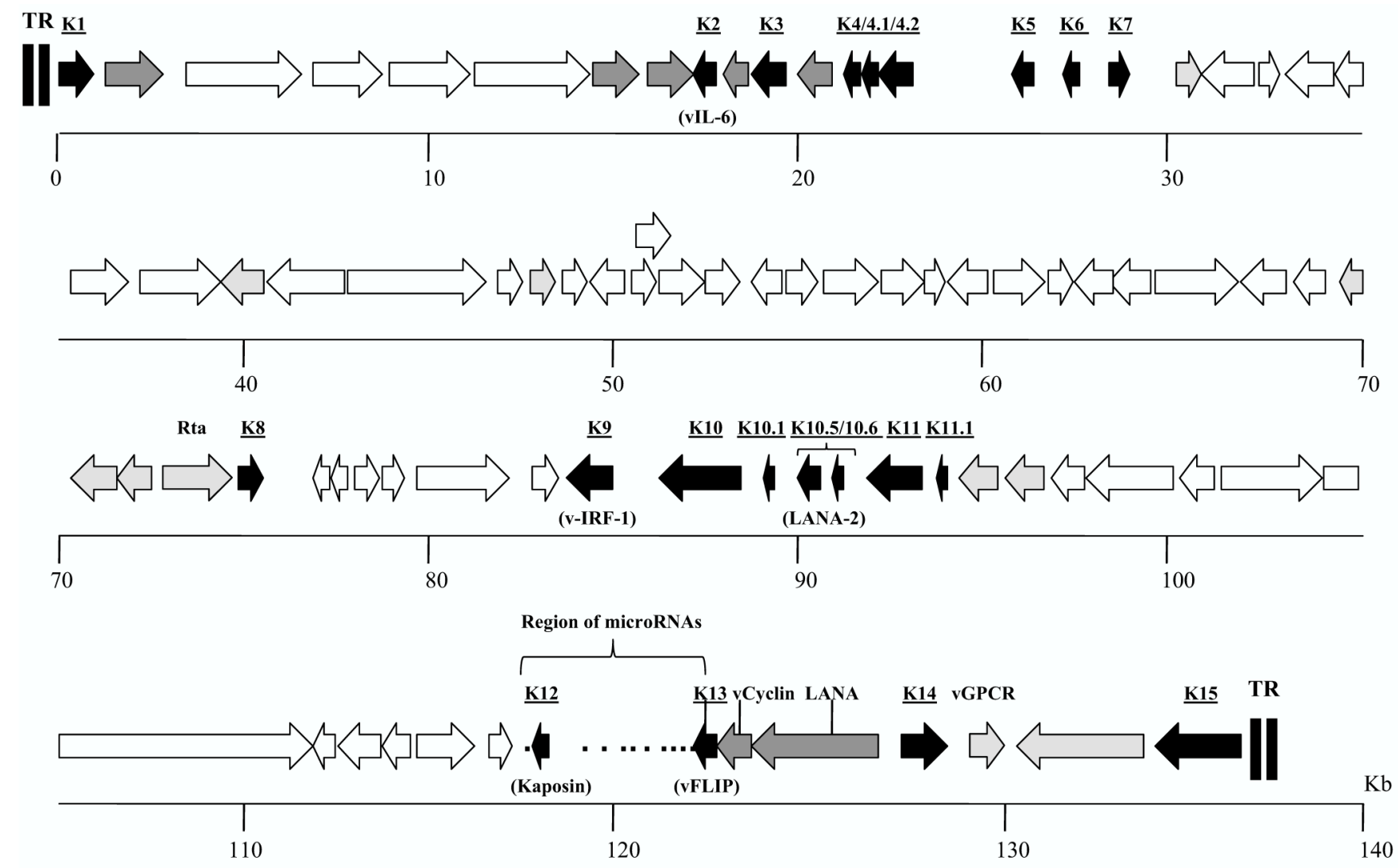

Fig. 1. The KSHV genomic open reading frames (ORFs)

The arrows represent individuals ORFs and the dots represent the KSHV encoded microRNAs. ORFs unique to KSHV are labeled K1 through K15 and are indicated by black arrows. Alternative names mentioned in this review for some of these unique KSHV genes are in parentheses. Additional ORFs discussed in this review paper are also labeled. The ORFs common to rhadinoviruses are indicated by dark gray arrows, ORFs common to other gammaherpesviruses (e.g. EBV) are indicated by light gray arrows, and ORFs common to most herpesviruses are indicated by white arrows. TR denotes terminal repeats. The numbers on demarcated lines specify the approximate genome positions in $\mathrm{Kb}$. 
Table 1

In situ detection of KSHV gene products in KS, PEL, and MCD

\begin{tabular}{|c|c|c|c|}
\hline & KS & PEL & MCD \\
\hline LANA & RNA \& protein & RNA \& protein & RNA \& protein \\
\hline vCyclin & RNA & RNA & RNA \\
\hline vFLIP & RNA & RNA & RNA \\
\hline Kaposin B & RNA & RNA \& protein & $?$ \\
\hline vIRF-3/LANA-2 & - & RNA \& protein & RNA \& protein ${ }^{*}$ \\
\hline vIL-6 & RNA \& protein & RNA \& protein & RNA \& protein \\
\hline K1 & RNA \& protein & RNA \& protein* & RNA \& protein \\
\hline vGPCR & RNA & RNA & RNA \\
\hline Rta/Orf50 & RNA & RNA & $?$ \\
\hline PF-8/Orf59 & RNA \& protein & RNA \& protein & RNA \& protein \\
\hline vIRF-1 & RNA & RNA & RNA \\
\hline & & &
\end{tabular}

Note:

represents a viral gene whose protein levels can be detected in only a small percentage of tumor cells. 


\section{Table 2}

\section{Unique ORFs encoded by KSHV}

\begin{tabular}{|c|c|c|}
\hline ORF & Alternative name & Functions \\
\hline $\mathrm{K} 1 *$ & VIP & $\begin{array}{l}\text { Transformation; B cell activation; inhibition of apoptosis; downregulation of surface B cell receptor } \\
\text { (BCR); activation of PI3K/Akt/mTOR kinases }\end{array}$ \\
\hline $\mathrm{K} 2 *$ & vIL-6 & IL-6 homolog; B cell proliferation; autocrine/paracrine signaling \\
\hline $\mathrm{K} 3$ & MIR1 & E3 ubiquitin ligase; immune evasion; inhibition of MHC class I and T cell killing \\
\hline K4 & vMIP-II; vMIP-1b; vCCL-2 & $\begin{array}{l}\text { MIP-I homolog; angiogenesis; CCR } 3 \text { and CCR } 8 \text { binding; chemoattraction of TH2 cells and } \\
\text { monocytes (immune modulation) }\end{array}$ \\
\hline $\mathrm{K} 4.1$ & vMIP-III; vBCK; vCCL3 & $\begin{array}{l}\text { TARC/eotaxin homolog; induction of VEGF-A and angiogenesis; CCR4 binding; chemoattraction of } \\
\text { TH2 cells (immune modulation) }\end{array}$ \\
\hline K5 & MIR2 & E3 ubiquitin ligase; immune evasion; inhibition of MHC class I, B7, and ICAM expression \\
\hline K6 & vMIP-I; vMIP-1a; vCCL-1 & $\begin{array}{l}\text { MIP-I homolog; angiogenesis; CCR5 and CCR8 binding; chemoattraction of TH2 cells and } \\
\text { monocytes }\end{array}$ \\
\hline K7 & Survivin; $\underline{\text { vIAP }}$ & Inhibitor of apoptosis protein (IAP) homolog; inhibition of vGPCR expression and function \\
\hline K8 & K-bZIP & $\begin{array}{l}\text { An immediate-early gene that represses RTA transactivation activity and Rta induction of KSHV lytic } \\
\text { cycle }\end{array}$ \\
\hline K8.1 & & Viral glycoprotein (structural protein) \\
\hline $\mathrm{K} 9 *$ & vIRF-1 & IRF homolog; Inhibition of type I interferon, p300, p53, and TGF- $\beta$; transformation \\
\hline K10 & vIRF-4 & IRF homolog \\
\hline $\begin{array}{l}\text { K10.1 } \\
\text { K10.5 } \\
\text { K10.6 }\end{array}$ & LANA-2 (K10.5); vIRF-3 & $\begin{array}{l}\text { IRF homolog; inhibition of type I interferon production and apoptosis (PKR- and caspase- } 3 \\
\text { mediated); inhibition of p53 and NFKB; inhibition of Fas-mediated apoptosis via inhibition of CD95L } \\
\text { surface expression }\end{array}$ \\
\hline $\begin{array}{l}\text { K11 } \\
\text { K11.1 } \\
\text { K11.5 }\end{array}$ & vIRF-2 (K11.5) & $\begin{array}{l}\text { IRF homolog; inhibition of type I interferon and NFKB; inhibition of Fas-mediated apoptosis via } \\
\text { inhibition of CD95L surface expression }\end{array}$ \\
\hline $\mathrm{K} 12 *$ & Kaposin & $\begin{array}{l}\text { Transformation (Kaposin A); cytokine and AU-rich mRNA stabilization by induction of p38 or MK2 } \\
\text { signaling (Kaposin B) }\end{array}$ \\
\hline $\mathrm{K} 13 *$ & vFLIP & FLIP homolog; transactivator of NFkB; anti-apoptotic function; transformation \\
\hline K14 & vOx-2 & $\begin{array}{l}\text { Ox-2 (CD200) homolog; downregulation of myeloid cell activation; regulation of inflammatory } \\
\text { cytokine production such as IL-1 } \beta \text {, TNF-a, IL-8, IFN- } \gamma \text { and IL-6 }\end{array}$ \\
\hline K15 & LAMP & $\begin{array}{l}\text { Activation of the intracellular signaling pathways (Ras/MAPK, NF- } \kappa \mathrm{B} \text {, and JNK/SAPK), leading to } \\
\text { IL-6, IL-8, and Cox-2 induction. A chimeric protein consisting of the CD8 extracellular domain of } \\
\text { CD8 and the K15 cytoplasmic domain could inhibit BCR signaling }\end{array}$ \\
\hline
\end{tabular}

Note: Due to the space restriction, only KSHV unique genes marked with an asterisk were discussed in more detail in the text. 